\title{
THREE MENTALLY RETARDED GIRLS OF SIMILAR APPEARANCE
}

\author{
BY \\ E. MILDRED CREAK, G. E. ROBERTS, and BARBARA E. CLAYTON \\ From the Departments of Psychological Medicine and Chemical Pathology, \\ The Hospital for Sick Children, Great Ormond Street, London
}

(RECEIVED FOR PLBLICATION DECEMBER 17, 1963)

In May 1962, a small girl, severely retarded and with some evidence of regression, was referred as possibly a psychotic child with autistic features. Since the regression seemed more evident than active withdrawal, physical investigations were made which will be described in greater detail later in this paper. It was, however, certain cruder physical characteristics that reminded one of us (E.M.C.) of another case seen a few weeks previously following an exactly similar referral. Soon after, a third girl was sent with a diagnosis, ? cerebral palsy with mental retardation. having been spotted by the family doctor as showing a significantly retarded rate of development in comparison with her twin brother.

It is perhaps a happy accident that three small girls whose resemblance to each other was striking were referred so close together that their cases could at once be compared and contrasted. Having done this, and with the clinical features in mind, two of us (B.E.C. and G.E.R.) were able to 'spot' two cases of similar appearance in different hospitals for the mentally retarded; one of these showed the deficient response to adrenocorticotrophic hormone (ACTH) seen in our own patients, but the other who was older and 8 years of age gave a normal response to ACTH.

What then are the clinical characteristics? All of them are deficient in growth; their appearance is "weedy" and unhealthy in the absence of any obvious cause. Their hair is straight, rather scanty, and tends to lie in wisps. Skin and colouring generally are not remarkable, but lack the gloss and vividness so often seen in healthy toddlers.

The diagnosis of 'autism' was suggested in two cases by a rather striking failure to contact. All three children showed repeated stereotyped movements, rocking to and fro, banging their heads, and two of them repeatedly banging their mouths with their fists and then cramming their fingers into their mouths. There was a suggestion of overbreathing in one girl as she did this, and once started, this activity continued. It could easily be interrupted by holding her hand but the pattern of activity was resumed as soon as the hand was released.

Similar repetitive movements are constantly observed in retarded and demented children, but the combination here with the growth failure and the forlorn appearance was quite striking. None of the three children appeared interested in people: of one, the mother said, 'she doesn't know or care who she is with". In the twin, this relative indifference and the retardation had been noted from birth. In the other two there was a picture of regression at the age of 2 years and 18 months respectively, and in the latter case development, albeit on normal lines, had been slow. In neither of the two children who regressed was there a suggestion of any concurrent physical illness.

These findings are summarized in Table 1 and the appearance of two of the patients (T.S. and F.B.) is shown in Fig. 1 and Fig. 2.

\section{Growth}

Heights and weights were recorded in terms of percentile status on charts prepared by Tanner and Whitehouse (1959).

All three children were considerably below the third percentile for height. T.S. and R.W. were below the third percentile for weight also, but F.B. was between the $3 \mathrm{rd}$ and 10 th for weight.

Early weight records were available for all three children. These are seen, again in terms of percentile status, in Fig. 3. All three curves showed a similar trend, each falling away progressively from their original status. In patients R.W. and F.B., in whom actual intellectual regression occurred, growth fell off between 9-18 months of age, and preceded the age at which mental deterioration occurred. 
TABLE 1

DEVELOPMENT OF THE CHILDREN

\begin{tabular}{|c|c|c|c|}
\hline & R.W. $\subsetneq$ born 9.2 .60 & F.B. $q$ born 28.8 .59 & $\begin{array}{l}\text { T.S. \& born } 9.10 .59 \\
\text { has normal twin brother }\end{array}$ \\
\hline First seen & 1.3 .62 & 11.5 .62 & 11.1 .62 \\
\hline Referred for: & ? autistic; onset at 18 months & ? autistic; onset 2 years & $\begin{array}{l}\text { ? cerebral palsy; backward } \\
\text { from birth }\end{array}$ \\
\hline Intellectual deterioration & $\begin{array}{l}\text { Previously slow but definite } \\
\text { deterioration with loss of } \\
\text { acquired skills }\end{array}$ & $\begin{array}{l}\text { Regarded as normal previously, } \\
\text { definite deterioration at } 2 \\
\text { yr. with loss of skills }\end{array}$ & Always backward \\
\hline Pregnancy & $\begin{array}{l}\text { Full term; normal second } \\
\text { pregnancy preceded by } \\
\text { healthy sister and one } \\
\text { miscarriage }\end{array}$ & $\begin{array}{l}\text { Full term; no specific illness } \\
\text { but mother 'never felt well' } \\
\text { second pregnancy; two } \\
\text { normal sibs }\end{array}$ & $\begin{array}{l}\text { Full term; pregnancy normal; } \\
\text { first pregnancy after six } \\
\text { years marriage; twin brother } \\
\text { and younger sib normal }\end{array}$ \\
\hline Birth weight & 7 lb. 1 oz $(3,203 \mathrm{~g})$ & 6 lb. 4 oz $(2,834 \mathrm{~g})$ & $\begin{array}{l}5 \text { lb. }(2,267 \mathrm{~g}) \text { (brother } \\
6 \mathrm{lb} .5 \mathrm{oz}(2,863 \mathrm{~g})\end{array}$ \\
\hline Delivery & Normal; no neonatal distress & $\begin{array}{l}\text { Normal delivery; 'took a } \\
\text { bit of reviving' }\end{array}$ & $\begin{array}{l}\text { Normal delivery; neonatal } \\
\text { condition normal }\end{array}$ \\
\hline Early feeding & Bottle fed without difficulty & $\begin{array}{l}\text { Breast fed for two months; } \\
\text { difficult feeder }\end{array}$ & $\begin{array}{l}\text { Bottle fed; slight feeding } \\
\text { difficulty }\end{array}$ \\
\hline Milestones & $\begin{array}{l}\text { Sat at } 8 \mathrm{mth} . ; \text { stood 'late'; } \\
\text { walked at } 1 \text { yr. } 9 \mathrm{mth} \text {. }\end{array}$ & $\begin{array}{l}\text { Sat at } 5 \text { mth.; stood at } 11-12 \\
\text { mth.; walked at } 15 \text { mth. }\end{array}$ & $\begin{array}{l}\text { Sat at } 1 \text { yr.; only just stood; } \\
\text { only just walked }\end{array}$ \\
\hline Feeding & $\begin{array}{l}\text { Eats well, but requires to } \\
\text { be fed }\end{array}$ & $\begin{array}{l}\text { Formerly fed herself; now } \\
\text { requires feeding and } \\
\text { dislikes chewing }\end{array}$ & $\begin{array}{l}\text { Makes no attempt to feed } \\
\text { herself }\end{array}$ \\
\hline Speech & Babbles, has said 'hello' & $\begin{array}{l}\text { Formerly said 'Mum' and } \\
\text { 'Dad'. but no speech now }\end{array}$ & No speech \\
\hline Sleep & Very good & $\begin{array}{l}\text { Wakes regularly, moans and } \\
\text { screams }\end{array}$ & $\begin{array}{l}\text { Disturbed at nights; wakeful; } \\
\text { 'sits and laughs her head off' }\end{array}$ \\
\hline Height (just before treatment) & $30 \frac{1}{2}$ in. $(76 \cdot 2 \mathrm{~cm})$. & $34 !$ in. $(86 \mathrm{~cm})$. & 291 in. $(74 \mathrm{~cm})$. \\
\hline $\begin{array}{l}\text { Height (after } 1 \mathrm{yr} . \text { of } \\
\text { treatment) }\end{array}$ & 323 in. $(83 \mathrm{~cm})$. & 36 in. $(91 \mathrm{~cm})$. & 33 in. $(84 \mathrm{~cm})$. \\
\hline Weight (just before treatment) & $20 \mathrm{lb} .(9 \cdot 07 \mathrm{~kg})$. & $23 \mathrm{lb} .6 \mathrm{oz} .(10.6 \mathrm{~kg})$. & $19 \mathrm{lb} .2 \mathrm{oz}(8 \cdot 7 \mathrm{~kg})$ \\
\hline $\begin{array}{l}\text { Weight (after } 1 \text { yr. of } \\
\text { treatment) }\end{array}$ & 24 lb. $(10.9 \mathrm{~kg})$. & 29 lb. 5 oz. $(13 \cdot 3 \mathrm{~kg})$ & 24 lb. (10.9 kg) \\
\hline
\end{tabular}

\section{Investigations}

A series of investigations was performed and the results are summarized in Tables 2 and 3 . Since all three children were below the third percentile for height and weight and there was no apparent cause for this, an attempt was made to assess the function of the anterior pituitary gland, using methods previously described (Schlesinger, Clayton, Bodian and Jones, 1963); in addition, urinary gonadotropins were estimated in R.W. and F.B. by a modified mouse uterine weight method (Fitschen and Clayton, to be published).

TABLE 2

INVESTIGATIONS

\begin{tabular}{|c|c|c|c|}
\hline & R.W. & F.B. & T.S. \\
\hline Neurological examination & $\begin{array}{l}\text { No focal signs: slight } \\
\text { generalized hypotonia }\end{array}$ & No focal signs: no hypotonia & $\begin{array}{l}\text { No focal signs; generalized } \\
\text { hypotonia; no cerebral palsy }\end{array}$ \\
\hline Intelligence test & $\begin{array}{l}\text { Untestable: not withdrawn; } \\
\text { failed to manipulate objects }\end{array}$ & $\begin{array}{l}\text { Untestable; failed to relate; } \\
\text { would not grasp objects }\end{array}$ & Severely retarded in all spheres \\
\hline EEG & $\begin{array}{l}\text { Marked generalized abnorm- } \\
\text { ality: during recording } \\
\text { seizure occurred (never } \\
\text { seen before) }\end{array}$ & $\begin{array}{l}\text { Diffuse abnormality without } \\
\text { paroxysmal features }\end{array}$ & Miid diffuse abnormality \\
\hline Skull radiograph & Normal & Normal & Normal \\
\hline Rectal biopsy & Normal & Not done & Not done \\
\hline
\end{tabular}




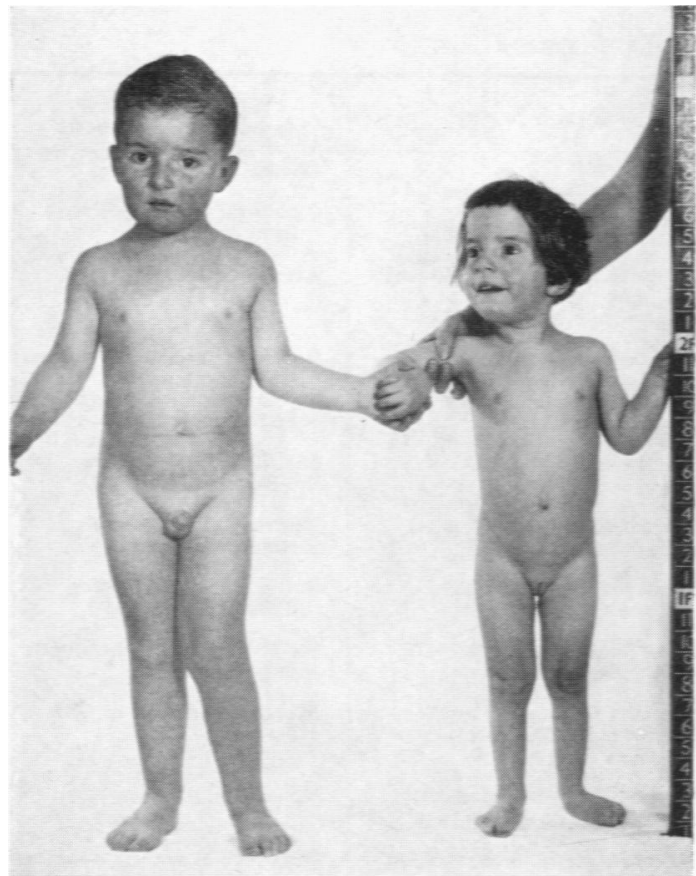

FiG. 1.-T.S. (aged 3 years) in comparison with her twin brother.

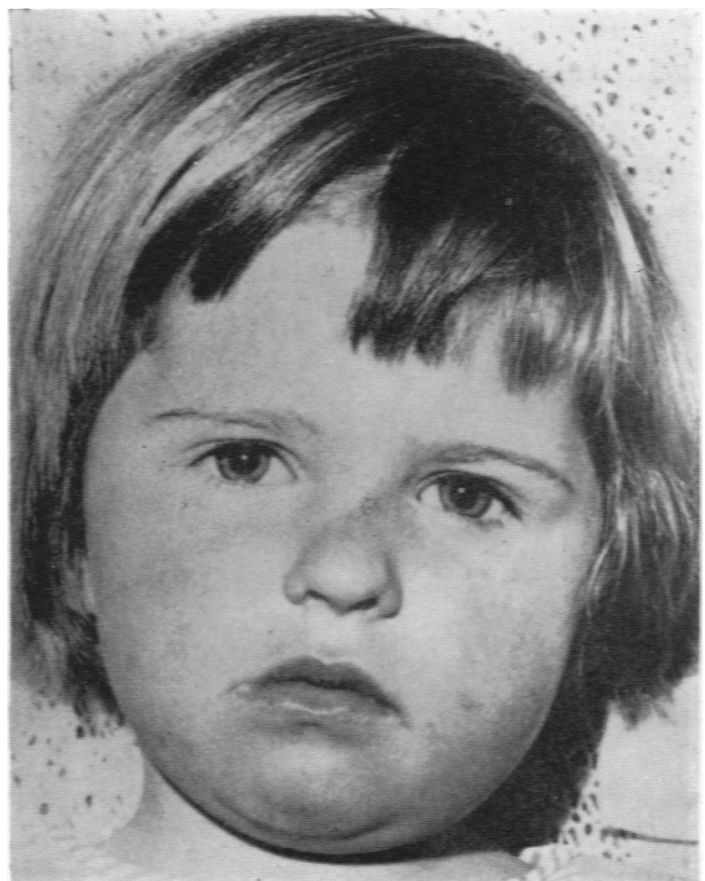

Fig. 2.-F.B. Copy of a portrait taken at the age of 2 years 10 months.

TABLE 3

BIOCHEMICAL INVESTIGATIONS

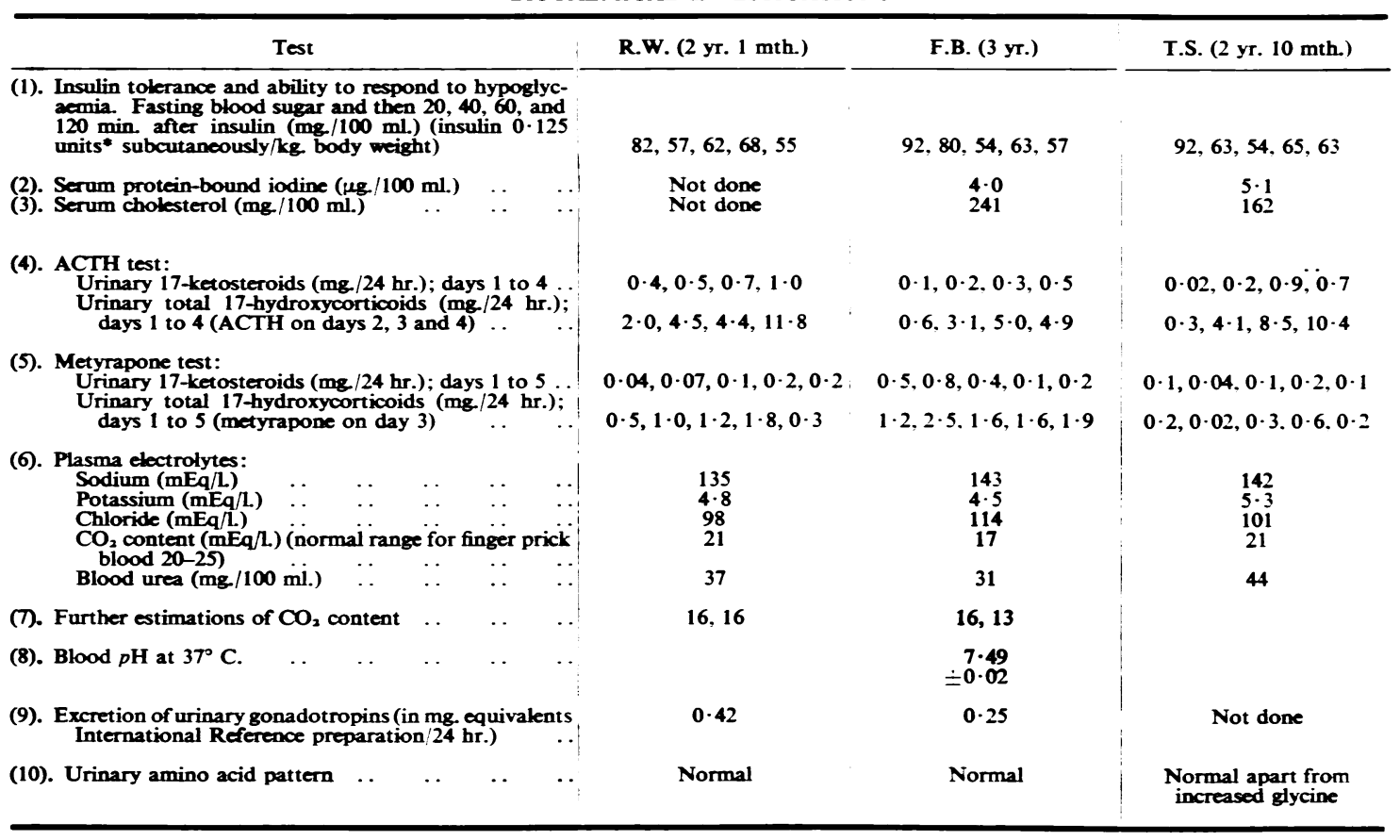

- This represents half the standard dose. 


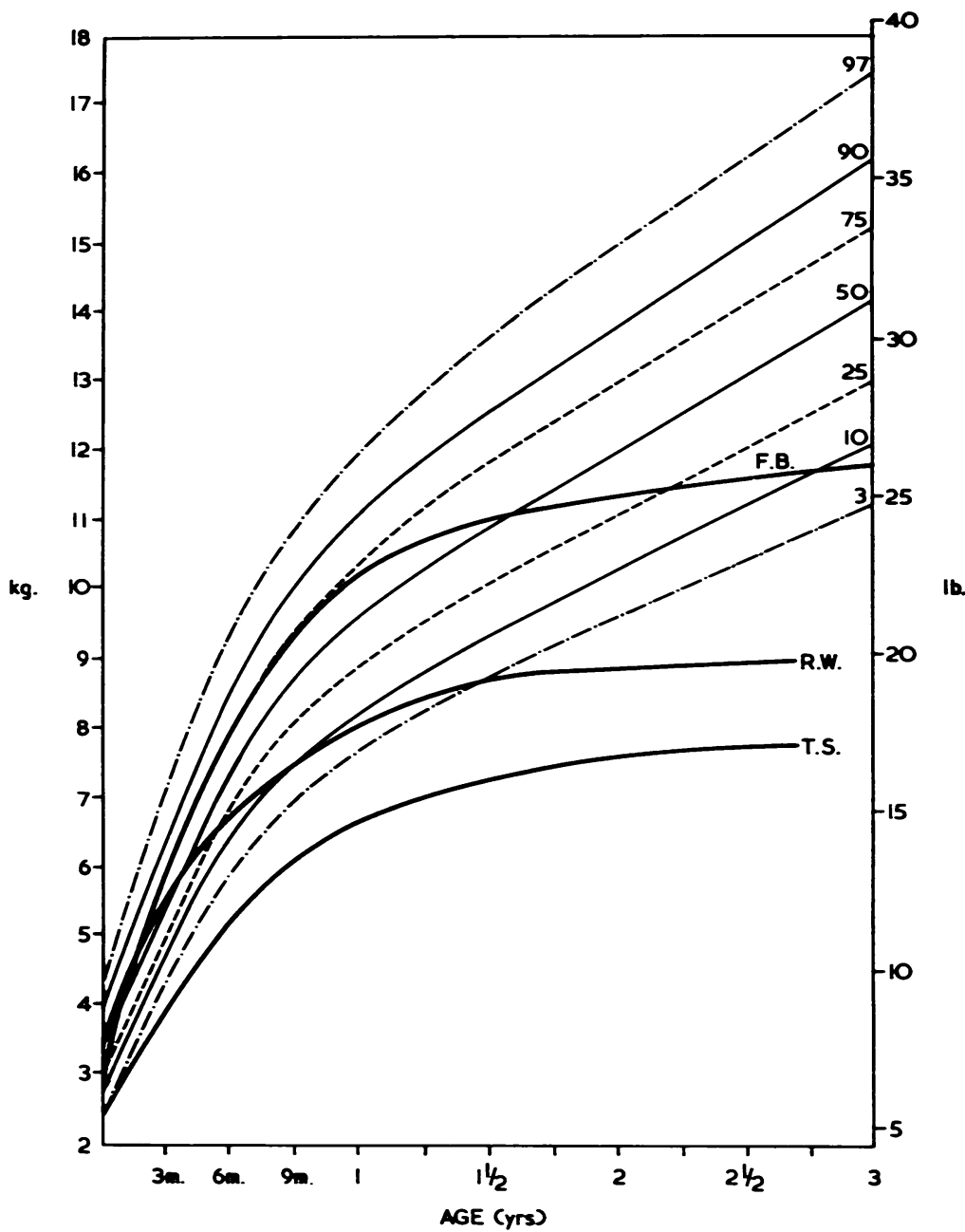

FIG. 3.-Weight record from birth to the commencement of treatment, charted according to Tanner and Whitehouse (1959).

All the patients were abnormally sensitive to insulin, and this finding was compatible with a diagnosis of hypopituitarism and/or poor adrenocortical activity (Fraser, Albright and Smith, 1941). The most striking finding was the deficient response to ACTH, since normal children excrete at least $20 \mathrm{mg}$. of total 17-hydroxycorticoids every 24 hours during this test (Clayton, Edwards and Renwick, 1963). Adrenocortical deficiency appeared to be secondary to a primary deficiency of adrenocorticotrophic hormone since there was no response to metyrapone ('metopirone') in R.W. and F.B. (the excretions of steroid were so low in T.S. during this test that no conclusion could be drawn from them). Serum protein-bound iodine was estimated in two of the children and was normal; gonadotropin was present in the urine of the two children in whom it was assayed. It is therefore suggested that there was a deficiency of adrenocorticotrophic hormone without a deficiency of thyrotropic or gonadotropic hormones. No information with respect to growth hormone was obtained.

In R.W. and F.B. the plasma $\mathrm{CO}_{2}$ content was low and was associated with very frequent attacks of overbreathing; the blood $p \mathrm{H}$ measured in F.B. was compatible with this. It is not known why overbreathing occurred.

\section{Treatment and Follow-up}

In view of the biochemical findings suggesting the possibility of a deficiency of pituitary adrenocorticotrophic hormone, it was decided to treat the children 
with ACTH, and 2.5 to 5 units of ACTH as Acthar gel (Armour Laboratories Ltd.) were given intramuscularly every morning. Each patient has now received treatment for approximately one year with assessment at regular monthly intervals.

There has been significant physical improvement in each child. They are livelier, less forlorn, and generally much healthier. There has, however, been no acceleration in the rate of growth in height so that they still remain dwarfed to the same degree that they showed before treatment was begun. The increases in height and weight are shown in Table 1.

The intellectual improvement is more difficult to assess. There has certainly been no further regression in any of them. The parents report subtle but non-dramatic improvements in F.B. and R.W., in particular a greater awareness of their surroundings and more contentment in their demeanour. It is impossible to say that such minor changes are due to the therapy; they may simply be due to the passage of time.

Two other developments have been noted over the last year. First, R.W. has developed epilepsy: there is no suggestion of this in the other two. Secondly, T.S. developed increasing pica, and as her father had been painting at home the child's blood lead was estimated: this was returned as $51 \mathrm{\mu g}$. $/ 100 \mathrm{ml}$. blood (normal up to $36 \mu \mathrm{g} . / 100 \mathrm{ml}$.). In view of this it was thought that some degree of lead poisoning was possibly contributing to her retardation and she was treated with penicillamine $150 \mathrm{mg}$. b.d. for one month. At the end of the month the blood lead had fallen to $29 \mu \mathrm{g} . / 100 \mathrm{ml}$., but no improvement was noted in the child.

\section{Discussion}

One task facing the child psychiatrist is to differentiate a confused developmental picture which, in effect, ends up as severe retardation. In this group the retardation is both mental and physical. This is no rarity, and the population of any hospital caring for severely retarded children tends to contain a number who look dystrophic in one way or another. Each clinical grouping that can be clarified is one step nearer to understanding some of the multiple factors operating to produce a severe retardation.

One feature that led to this group being investigated was that, as well as being very similar in behaviour, they were all girls. Since the autistic psychosis affects more boys than girls, three girls in a row was a suggestive combination. Another point to note is that the history of onset varied in the three children; this may well relate to the stage of development that each had reached when the adverse factor became operative. In R.W. development petered out; in F.B. there was a noticeable regression and T.S. was retarded from birth. It is deceptively easy to ignore the similarity and call one an autistic psychotic, the others 'simply' severe and mild retardation, without further query as to the basic cause. It is clearly necessary to look further into the mechanisms whereby a hormonal deficiency is associated with impaired intellectual function and growth.

The importance of recognizing this association lies in the possibility of being able to offer earlier treatment to future cases. Treatment did not produce a significant improvement in the intellectual functioning of our cases. This may have been because it was given too late, at the stage when cerebral damage had become irreversible. In cases like F.B. and R.W. (showing regression at 2 years and 18 months respectively) it may be that if treatment is commenced when regression begins then the progress of the disease that is overtaking them could be halted. This is always difficult when onset and deterioration are insidious, but clearly any suspiciously similar cases should have the benefit of the appropriate investigations.

\section{Summary}

A description is given of three small girls with a similar forlorn appearance, mental retardation, failure of growth, and adrenocortical insufficiency probably secondary to a lesion of the anterior pituitary gland.

We thank Dr. V. Cowie, Dr. L. Goldie, and Dr. G. O'Gorman for allowing us to investigate their patients, and Dr. G. B. Simon for his co-operation.

One of us (G.E.R.) gratefully acknowledges financial assistance from the Nuffield Foundation. We are indebted to Mr. D. Martin for the illustrations.

\section{REFERENCES}

Clayton, B. E., Edwards. R. W. H. and Renwick, A. G. C. (1963). Adrenal function in children. Arch. Dis. Childh., 38, 49.

Fraser. R.. Albright, F. and Smith. P. H. (1941). The value of the glucose tolerance test, the insulin tolerance test. and the glucose insulin tolerance test in the diagnosis of endoctinologic disorders of glucose metabolism. J. clin. Endocr., 1, 297.

Schlesinger, B.. Clayton. B., Bodian. M. and Jones, K. V. (1963). Typus degenerativus amstelodamensis. Arch. Dis. Childh.. 38, 349.

Tanner, J. M. and Whitehouse, R. H. (1959). Height and Weight Standard Charts. Printed by Joseph Collard \& Sons. 24 Litchfield Street, Charing Cross Road, London, W.C.2. 